\author{
Błażej Lepczyński, Eugeniusz Gostomski \\ Uniwerstytet Gdański \\ e-mails: blazej.lepczynski@gmail.com; egostomski@wp.pl
}

\title{
ROLA SYSTEMÓW OCHRONY INSTYTUCJONALNEJ \\ WE WZMACNIANIU BEZPIECZEŃSTWA \\ FINANSOWEGO BANKOWOŚCI SPÓLDZIELCZEJ \\ W POLSCE
}

\section{THE ROLE OF INSTITUTIONAL PROTECTION \\ SCHEMES IN THE ENHANCEMENT FINANCIAL SECURITY OF POLISH COOPERATIVE BANKS}

DOI: $10.15611 / \mathrm{pn} .2018 .531 .27$

JEL Classification: G21

Streszczenie: Ważnym elementem uzupełniającym architekturę bezpieczeństwa finansowego polskich banków spółdzielczych są niedawno utworzone systemy ochrony instytucjonalnej (IPS-y). Celem badania była ocena roli IPS-ów we wzmacnianiu bezpieczeństwa finansowego banków spółdzielczych. Z uwagi na krótki okres istnienia tych rozwiązań w rozważaniach skupiono się na teoretycznej analizie mechanizmów funkcjonowania systemów ochrony instytucjonalnej w aspekcie ich zdolności do wczesnego wykrywania potencjalnych problemów finansowych uczestników systemów oraz w aspekcie utworzonych mechanizmów pomocowych. Wyniki analiz wskazują, że w przyszłości IPS-y powinny skutecznie zapobiegać kryzysom i bankructwom banków w polskim systemie bankowości spółdzielczej poprzez wczesne wykrywanie problemów finansowych i zasilanie finansowe banków spółdzielczych w sytuacji kryzysowej. W ramach IPS-ów rozwijane są bowiem systemy ocen ryzyka banków oraz mechanizmy pomocowe. Konieczne jest jednak doskonalenie przyjętych rozwiązań, zwłaszcza w obrębie bardzo istotnej z punktu widzenia bezpieczeństwa funkcji prewencyjnej, w przypadku której zidentyfikowaliśmy lukę w postaci ograniczonej zdolności prognostycznej stosowanych systemów ocen banków. Pozytywnie z punktu widzenia roli IPS-ów we wzmacnianiu bezpieczeństwa banków spółdzielczych oceniamy natomiast konstrukcję funduszy wsparcia oraz wzrost ich wielkości w latach 2015-2017.

Slowa kluczowe: bank spółdzielczy, ochrona instytucjonalna, stabilność finansowa.

Summary: Institutional Protection Schemes are an important element of the financial stability architecture of cooperative banks. The main purpose of this study is to assess the role of institutional protection systems for the financial security of cooperative banks. The analysis was of theoretical nature. The methodology was based on the assessment of banks rating mechanism and banks support mechanism. The establishment of institutional protection schemes has contributed to the ordering of supervisory functions. The study shows that 
institutional protection systems should in the future play a positive role in strengthening the safety and resilience of polish cooperative banks to external shocks. However, we indentified problem of limited predictive capability of rating procedures implemented in institutional protection systems in Poland. From the point of view of the role of IPS in strengthening financial stability of cooperative banks, we positively assess the construction of support funds.

Keywords: cooperative bank, institutional protection, financial stability.

\section{Wstęp}

Istotnym wydarzeniem o potencjalnie dużym znaczeniu dla przyszłości polskiej bankowości spółdzielczej było powstanie w 2015 r. w ramach zrzeszeń dwóch systemów ochrony instytucjonalnej, określanych w skrócie IPS-ami (Institutional Protection Scheme).

Ich utworzenie było związane z koniecznością dostosowania warunków funkcjonowania polskiej bankowości spółdzielczej do wymogów regulacyjnego pakietu unijnego CRR/CRD. Pojawienie się IPS-ów przybliża polską bankowość spółdzielczą do rozwiązań znanych w europejskiej bankowości i porządkuje funkcje nadzorcze. Banki spółdzielcze to głównie bardzo małe instytucje, mające często problemy $\mathrm{z}$ wypełnianiem rosnących wymagań regulacyjnych w dziedzinie bezpieczeństwa finansowego. IPS-y stanowią odpowiedź na ten problem, ponieważ ułatwiają bankom spółdzielczym spełnianie norm nadzorczych. Kluczowe znaczenie ma jednak utworzenie w ich ramach mechanizmów, które mogą zwiększać odporność banków na ewentualne kryzysy.

Celem badania była ocena znaczenia systemów ochrony instytucjonalnej we wzmacnianiu bezpieczeństwa finansowego banków spółdzielczych. W pierwszej części artykułu przybliżono funkcje, organizację i zasady działania IPS-ów. Natomiast $\mathrm{w}$ drugiej części przedstawiono wyniki teoretycznej analizy mechanizmów wpływu IPS-ów na bezpieczeństwo banków spółdzielczych. W badaniu przyjrzeliśmy się bliżej rozwiązaniom zastosowanym w polskich IPS-ach pod kątem ich potencjalnego wpływu na bezpieczeństwo. Metodyka badawcza sprowadzała się do oceny mechanizmów wczesnego ostrzegania oraz pomocowych na podstawie kryteriów zaproponowanych do analiz IPS-ów przez Europejski Bank Centralny oraz kryteriów autorskich.

Wpływ na zdolność do pokrywania strat przez IPS-y ma również kondycja finansowa uczestników IPS-ów i wielkość zgromadzonych środków finansowych w ramach funduszy pomocowych. Dlatego analizę uzupełniono o ocenę kondycji finansowej banków-uczestników systemów oraz o analizę wielkości funduszy zgromadzonych w ramach utworzonych w IPS-ach mechanizmów wsparcia. 


\section{Prezentacja podstaw oraz zasad funkcjonowania systemów ochrony instytucjonalnej}

Celem systemów ochrony instytucjonalnej jest wzmacnianie bezpieczeństwa finansowego banków spółdzielczych poprzez kooperację w dziedzinie bezpieczeństwa oraz przeciwdziałanie utracie płynności i wypłacalności.

IPS-y są koncepcją znaną w Europie od lat 70. XX w. ${ }^{1}$ Około 50 proc. wszystkich instytucji kredytowych w strefie euro funkcjonuje w ramach IPS-ów, co podkreśla znaczenie tego typu rozwiązań dla bezpieczeństwa finansowego europejskiego systemu bankowego [Vesala 2016, s. 5]. Rozwiązanie to jest preferowane przez europejskiego regulatora [Zygierewicz 2014, s. 283].

Do końca $2015 \mathrm{r}$. w polskim systemie bankowym IPS-y nie funkcjonowały. $\mathrm{Na}$ ich powstanie w ramach bankowości spółdzielczej wpłynęły nowe postkryzysowe regulacje w UE. W Polsce ramy prawne funkcjonowania systemów ochrony instytucjonalnej zostały wprowadzone wraz z nowelizacją ustawy o funkcjonowaniu banków spółdzielczych, ich zrzeszaniu się i bankach zrzeszających.

Tworzenie IPS-ów motywuje się korzyściami dla banków spółdzielczych i całego systemu bankowego. Do najważniejszych korzyści zalicza się [Koleśnik 2013, s. 290]:

- „obniżenie wymogów kapitałowych oraz zwiększenie możliwości spełniania normy płynności krótkoterminowej LCR";

- „możliwość podniesienia efektywności wykorzystania środków uczestników systemu";

- „możliwość ujednolicenia systemów zarządzania ryzykiem i płynnością w ramach systemu".

- „możliwość całościowego przeglądu ryzyka poszczególnych uczestników oraz całego systemu".

Wskazane korzyści sprowadzają się do ułatwień w zakresie osiągania wymogów kapitałowych i płynnościowych, poprawy jakości zarządzania ryzykiem oraz zwiększenia możliwości monitorowania systemu banków spółdzielczych. Powyższą listę korzyści należy uzupełnić o mechanizmy pomocowe zabezpieczające banki na wypadek utraty płynności czy wypłacalności.

Systemy ochrony instytucjonalnej zmieniają strukturę funkcjonowania bankowości spółdzielczej, ale nie powodują odejścia od zasady zrzeszania się banków spółdzielczych. Funkcjonowanie banków spółdzielczych w ramach IPS-ów ma w Polsce charakter dobrowolny i opiera się na dwóch mechanizmach o charakterze ochronnym. Pierwszym mechanizmem jest wsparcie płynności, drugim natomiast tzw. fundusz pomocowy.

\footnotetext{
1 Jednym z bardziej interesujących systemów ochrony instytucjonalnej banków spółdzielczych w Europie jest system niemiecki. Dzięki istniejącej od 1934 r. ochronie instytucjonalnej banków w Niemczech nie upadł tam żaden bank spółdzielczy. Obecnie w Niemczech funkcjonuje dualny system gwarancji depozytów i ochrony instytucjonalnej banków spółdzielczych przed upadłością.
} 
Zasadniczo IPS-y spełniają następujące funkcje:

1) monitorującą,

2) audytowania,

3) dyscyplinującą,

4) ochronno-pomocową,

5) standaryzującą.

Pierwsza $\mathrm{z}$ wymienionych funkcji sprowadza się do monitorowania standingu finansowego banków spółdzielczych w celu wczesnego wykrycia banków zagrożonych utratą płynności lub niewypłacalnością. Druga funkcja związana jest z realizowanymi przez systemy ochrony instytucjonalnej cyklicznymi audytami banków spółdzielczych, w ramach których ocenia się ryzyko banków spółdzielczych, bada procesy i procedury w bankach. Kolejna funkcja daje możliwość dyscyplinowania banków spółdzielczych, które np. naruszają zasady działania danego IPS-u. Funkcja ochronno-pomocowa wynika natomiast z możliwości wsparcia finansowego banków spółdzielczych przez IPS z wcześniej zgromadzonych środków w sytuacji wystąpienia problemów finansowych. Ostatnią wymienioną funkcją IPS-ów jest funkcja standaryzująca zarządzanie ryzykiem w bankach spółdzielczych. Ta funkcja pozwala narzucić bankom względnie jednolite zasady i metody zarządzania ryzykiem. Realizując powyższe funkcje, IPS-y powinny pozytywnie wpływać na bezpieczeństwo banków spółdzielczych.

Zasady funkcjonowania IPS-u określają zapisy w ustawie o funkcjonowaniu banków spółdzielczych, ich zrzeszaniu się i bankach zrzeszających, uregulowania zawarte w umowie systemu ochrony oraz zapisy w statucie jednostki zarządzającej. W myśl art. 22b wskazanej ustawy „banki zrzeszające lub banki spółdzielcze lub bank zrzeszający oraz zrzeszone z nim banki spółdzielcze mogą utworzyć system ochrony na podstawie umowy systemu ochrony" [Ustawa z 7 grudnia 2000]. Uczestnikami takiego systemu są banki, które go utworzyły, oraz te, które w późniejszym okresie do niego przystąpiły.

W myśl z art. 22d przywoływanej ustawy systemem zarządza bank zrzeszający lub jednostka zarządzająca w formie spółki akcyjnej (każdy uczestnik IPS-u musi objąć i posiadać co najmniej minimalną liczbę akcji określoną w statucie spółki) lub spółdzielni osób prawnych, której członkami są bank zrzeszający i banki spółdzielcze. W Polsce IPS-y funkcjonują, opierając się na tym ostatnim rozwiązaniu.

Zgodnie ze swoimi statutami jednostki zarządzające IPS-ami podejmują działania mające zapewnić członkom systemów płynność i wypłacalność. Działania sprowadzają się do szacowania i monitorowania ryzyka, audytowania standingu finansowego członków IPS-ów oraz udzielania im pomocy finansowej² ${ }^{2}$.

Ustawowo organami jednostki zarządzającej w formie spółdzielni są walne zgromadzenie członków, rada nadzorcza i zarząd [Ustawa z 7 grudnia 2000, art. 22j]. Organ zarządzający „może nakazać uczestnikowi systemu (...) zaprzesta-

2 Zob. Statuty IPS-ów przywołane w literaturze. 
nie działań naruszających prawo lub postanowienia umowy systemu". Jeśli uczestnik systemu rażąco narusza prawo lub umowę systemu, organ zarządzający może wystąpić o odwołanie członków rady nadzorczej lub zarządu uczestnika systemu. W przypadkach określonych w ustawie organ zarządzający może również wystąpić do KNF o ustanowienie kuratora lub zarządu komisarycznego [Ustawa z 7 grudnia 2000, art. 22j].

Banki spółdzielcze przystępują do systemów ochrony instytucjonalnej po złożeniu instytucji zarządzającej deklaracji członkowskiej i podjęciu przez zarząd jednostki zarządzającej uchwały o przyjęciu banku spółdzielczego do systemu ochrony [Statut Spółdzielni, s. 4]. Członkostwo ustaje m.in. na skutek wypowiedzenia umowy przez członka IPS-u, wykluczenia, wykreślenia [Statut Spółdzielni, s. 4]. Banki przystępujące poddawane są ocenie $\mathrm{i}$ audytowi, po to żeby uczestnicy systemu spełniali wysokie standardy w zakresie kondycji finansowej; IPS-y oceniają również ryzyko wejścia danego banku dla całego systemu.

Wsparcie płynności zapewnia mechanizm ustalony w banku zrzeszającym lub jednostce zarządzającej opierający się na minimum depozytowym. Sprowadza się to do tego, że każdy uczestnik takiego systemu musi utrzymywać odpowiedni poziom zablokowanych środków (obliczanych jako procent depozytów), które są lokowane w instrumentach finansowych charakteryzujących się relatywnie wysoką płynnością.

Depozyt obowiązkowy spełnia podwójną rolę [System Ochrony SGB 2016]. Pierwsza ma charakter formalny i związana jest ze wskaźnikiem płynności krótkoterminowej LCR, którego wypełnianie może być realizowane na zasadzie zagregowanej. Realny wymiar depozytu obowiązkowego sprowadza się do zapewnienia środków na wypadek trudności z płynnością banku zrzeszonego w ramach IPS-u.

Fundusz pomocowy (nazywany również zabezpieczającym) tworzony jest solidarnie z wpłat uczestników IPS-u. Jego podstawowym celem jest ochrona wypłacalności banków spółdzielczych i przeciwdziałanie bankructwom.

Uczestnicy IPS-ów mogą korzystać z pomocy bezzwrotnej i zwrotnej, która co do zasady jest podstawową formą pomocy. Pomoc bezzwrotna może być udzielona $\mathrm{w}$ formie pożyczki na wsparcie płynności uczestnika, pożyczki restrukturyzacyjnej na wsparcie działań mających na celu usunięcie groźby niewypłacalności uczestnika, gwarancji, poręczenia, nabycia wierzytelności, wniesienia wkładów pieniężnych do banku spółdzielczego itp. [Benyskiewicz i in. (red.) 2017, s. 47-50].

Banki spółdzielcze zgodnie z zasadami działania IPS-ów mają obowiązek lokowania środków pomocowych (minimum depozytowego oraz funduszu pomocowego) w banku zrzeszającym [NBP 2017, s. 126].

Operacyjne funkcjonowanie systemu polega na współpracy banków spółdzielczych, a za pomocą kryteriów ekonomicznych określa się wysokość opłat poszczególnych banków spółdzielczych. Jednostka zarządzająca IPS-em przeprowadza audyty poszczególnych banków, ponieważ ma kompetencje umożliwiające przeprowadzanie działań kontrolnych. System ma charakter systemu wczesnego ostrzega- 
nia. Po dostrzeżeniu problemów podejmuje się w jego ramach interwencję, a rozwiązanie problemu następuje poprzez wsparcie płynności czy połączenia banków.

IPS-y wymagają zatwierdzenia przez KNF i są przez tę instytucję nadzorowane. KNF ma więc możliwość ingerencji w funkcjonujący system ochrony, co powinno zapewniać wysoką jakość przyjętych rozwiązań. W ramach funkcji nadzorczej KNF, zgodnie z art. 22n pkt 2 ustawy o funkcjonowaniu banków spółdzielczych, ich zrzeszaniu się i bankach zrzeszających, dokonuje oceny sytuacji finansowej systemu IPS, jakości zarządzania systemem oraz bada udzielane kredyty, pożyczki pieniężne, akredytywy, linie płynnościowe czy gwarancje. Funkcja nadzorcza wiąże się również z możliwością wydawania zaleceń jednostce zarządzającej IPS-em (art. 22n pkt 4).

Omawiając zasady funkcjonowania IPS-ów, należy również przyjrzeć się relacjom między utworzonymi systemami ochrony a bankami zrzeszającymi. Wskazuje się, że IPS-y zmieniają pozycję banku zrzeszającego, uwalniając go od funkcji kontrolno-nadzorczych, przy wzroście roli funkcji biznesowych [Szambelańczyk 2017]. Żeby zrozumieć istotę tej zmiany, należy przypomnieć, że akcjonariuszami banków zrzeszających są banki spółdzielcze. W strukturze bez IPS-ów bank zrzeszający pełnił również funkcje nadzorcze w odniesieniu do banków spółdzielczych, które z kolei nadzorowały bank zrzeszający w ramach uprawnień właścicielskich. Zniknięcie wraz z powstaniem IPS-ów tego problemu stwarza szansę skoncentrowania się banków zrzeszających na zadaniach wpierających rozwój banków spółdzielczych. Natomiast będąc członkiem IPS-u, bank zrzeszający funkcjonuje na takich samych zasadach jak banki spółdzielcze.

IPS-y to nie jedyny możliwy model funkcjonowania bankowości spółdzielczej. Innym rozwiązaniem wskazanym w cytowanej ustawie (w rozdziale $3 \mathrm{~b}$ ) jest zrzeszenie zintegrowane. W Polsce takie zrzeszenie otrzymało zgodę KNF-u i będzie funkcjonowało pod nazwą Polskiego Banku Apeksowego SA. W skład zrzeszenia zintegrowanego wejdzie prawdopodobnie ponad pięćdziesiąt banków spółdzielczych, które obecnie nie są w IPS-ach. Bank apeksowy to nowe rozwiązanie na polskim rynku, łączące w sobie elementy banku zrzeszającego i systemu ochrony instytucjonalnej.

Powstawanie zrzeszenia zintegrowanego w polskiej bankowości spółdzielczej jest krytykowane. Wskazuje się m.in. na strukturalną słabość ekonomiczną banków spółdzielczych przystępujących do zrzeszenia zintegrowanego, zwłaszcza w zakresie jakości kredytów i poziomu rezerw. „Banki poza IPS wykazują zdecydowanie niższe wyrezerwowanie należności zagrożonych od sektora niefinansowego niż banki spółdzielcze uczestniczące w systemach ochrony" [KNF 2017b, s. 23]. Podkreśla się również, że IPS-y są rozwiązaniem znacznie lepiej zdefiniowanym w ustawie, zwłaszcza w zakresie funkcji pomocowej, przez co są preferowane przez KNF.

Reasumując, IPS-y tworzą nowe ramy bezpieczeństwa banków spółdzielczych w Polsce. Zygierewicz wskazuje, że system ochrony instytucjonalnej „daje silne 
gwarancje istnienia wszystkich podmiotów” [Zygierewicz 2014, s. 286]. „Uczestnicy systemu zyskują większe bezpieczeństwo funkcjonowania i sygnał dla klientów, że taki przypadek jak SK Banku (w 2015 roku) nie będzie mógł się powtórzyć" [Kata 2016, s. 137]. Przedstawione rozwiązanie w formie IPS-ów jest również pozytywnie oceniane przez NBP. W raporcie o rozwoju systemu finansowego w $2016 \mathrm{r}$. stwierdzono, że „(..) większa integracja w ramach IPS wydaje się niezbędna dla poprawy zyskowności banków i umożliwienia im kontynuacji podnoszenia kapitałów regulacyjnych (...)" [NBP 2017, s. 123].

\section{IPS jako system wzmacniania bezpieczeństwa banków spóldzielczych}

IPS-y mogą stać się ważnym elementem architektury bezpieczeństwa finansowego polskich banków spółdzielczych, zwłaszcza że w ich ramach na koniec marca 2018 r. działało 88,4 proc. polskich banków spółdzielczych [KNF 2018, s. 19]. W innych krajach ,przez dziesięciolecia, a w szczególności w czasie ostatnich zawirowań finansowych, IPS-y dowiodły swojej skuteczności” [EACB 2011, s. 4].

Poszukując odpowiedzi na pytanie, jaką rolę mogą odgrywać IPS-y we wzmacnianiu bezpieczeństwa finansowego polskiej bankowości spółdzielczej, skupiliśmy się na przeprowadzeniu teoretycznej analizy oddziaływania tego typu systemów na bezpieczeństwo banków. Oceniając przyjęte w polskich IPS-ach rozwiązania, skoncentrowaliśmy się na aspektach związanych z monitorowaniem i limitowaniem ryzyka oraz na funkcji pomocowej. Są to z punktu widzenia bezpieczeństwa najważniejsze elementy tego typu systemów. Celem pierwszego elementu jest ograniczanie zjawiska utraty płynności i bankructwa poprzez wczesne wykrywanie tego typu problemów. Drugi element ma natomiast zapewniać wsparcie finansowe w sytuacji zagrożenia utratą płynności lub niewypłacalnością.

IPS-y można interpretować jako prywatny bail out, zapewniający ochronę zewnętrznym wierzycielom systemu [Choulet 2017, s. 7]. Teoretycznie tego typu rozwiązania służą wzmacnianiu bezpieczeństwa banków, jednak trzeba pamiętać również, że mogą prowadzić do wzrostu hazardu moralnego i ryzyka zarażania [Choulet 2017, s. 7]. W dużej mierze zależy to od konstrukcji systemu.

Do oceny polskich IPS-ów wykorzystano kryteria analizy przedstawione przez Europejski Bank Centralny (EBC) i kryteria autorskie. Możliwości ochrony banków przed bankructwem zależą także od sytuacji finansowej uczestników systemu oraz od wielkości funduszy pomocowych. Dlatego poddano również ocenie kondycję finansową banków w IPS-ach oraz poziom zgromadzonych środków. Badanie opierało się na informacjach ogólnie dostępnych oraz zawartych w dokumentach i raportach przedstawianych przez IPS-y.

Tworzenie IPS-ów wynika z potrzeby ochrony banków spółdzielczych przed bankructwem wynikającym z utraty płynności lub wypłacalności. Chodzi również 
o to, żeby koszty ratowania banków ponosili w pierwszej kolejności uczestnicy systemu bankowości spółdzielczej, a nie podatnicy.

Problemy z płynnością i wypłacalnością biorą się najczęściej z zaniedbań w obszarze zarządzania ryzykiem w bankach lub mogą być inicjowane czynnikami zewnętrznymi. Model biznesowy banków spółdzielczych opiera się na działalności depozytowo-kredytowej, stąd też szczególnie niebezpieczne jest zbyt wysokie ryzyko kredytowe, przejawiające się w niskiej jakości kredytów, oraz ryzyko utraty reputacji. Odporność małych banków spółdzielczych na zjawiska kryzysowe jest $\mathrm{z}$ reguły ograniczona $\mathrm{z}$ uwagi na ich słabość kapitałową oraz mniejsze niż dużych banków możliwości pozyskania środków z rynku. Uzasadnione jest więc tworzenie systemów zwiększających bezpieczeństwo, funkcjonujących na zasadzie kooperacji banków w dziedzinie bezpieczeństwa i wzajemnego ubezpieczania pozycji płynnościowej i adekwatności kapitałowej. Teoretycznie wzmacnianie bezpieczeństwa opiera się na dwóch mechanizmach:

1) wczesnego wykrywania problemów finansowych w bankach spółdzielczych i limitowania ryzyka, tak żeby nie dopuścić do sytuacji, w której konieczne byłoby zastosowanie wsparcia finansowego,

2) pomocowego, którego celem jest zapewnienie wsparcia finansowego w momencie zagrożenia płynności lub wypłacalności.

Ocena systemów ochrony insty tucjonalnej z perspektywy wzmacniania bezpieczeństwa powinna się zatem sprowadzać do analizy tych dwóch mechanizmów.

IPS tym lepiej chroni bezpieczeństwo banków, im wcześniej wykryje potencjalne zagrożenia dla płynności i wypłacalności. Teoretycznie IPS zwiększa bezpieczeństwo banków poprzez prewencję, tak żeby nie doszło do sytuacji, w której potrzebna byłaby pomoc. Wykrywanie problemów banków z odpowiednim wyprzedzeniem zależy od jakości wdrożonego systemu oceny banków. Zgodnie z kryteriami EBC ważne jest, czy system klasyfikuje banki zgodnie z ich ryzykiem w celu umożliwienia wczesnej interwencji, czy instytucje członkowskie są zobowiązane do dostarczania danych dotyczących ryzyka w regularnych odstępach czasu, czy IPS ma możliwość wpływania na banki poprzez wydawanie zaleceń i instrukcji w zakresie ryzyka [ECB 2016].

Wyniki oceny systemów monitorowania banków w IPS-ach przedstawiono w tabeli 1.

W polskich IPS-ach podstawową rolę w ocenie banków odgrywają systemy punktowe. Ich znaczenie podkreśla fakt, że nie służą tylko do oceny banków, ale także do ustalania wysokości wnoszonych opłat na fundusz pomocowy.

W świetle teorii oceny banków w badanych systemach uwzględnia się najistotniejsze kryteria oceny banków, a ocena ma charakter wielowymiarowy. Problemem może być jednak restrykcyjność ocen, ponieważ oceniane podmioty są równocześnie członkami jednostki zarządzającej IPS-em, co powoduje konflikt interesów. Kolejnym problemem jest podejście do oceny oparte na koncepcji point-in-time, co oznacza, że ocenia się bieżącą sytuację banku. W takiej sytuacji rola progno- 
Tabela 1. Ocena wybranych elementów systemów oceny banków stosowanych w IPS-ach

\begin{tabular}{|l|l|}
\hline \multicolumn{1}{|c|}{ Kryterium } & \multicolumn{1}{|c|}{ Ocena } \\
\hline $\begin{array}{l}\text { Czy nadawane bankom oceny mają charakter } \\
\text { mierzalny? }\end{array}$ & $\begin{array}{l}\text { Tak, do oceny banków stosuje się kryteria mie- } \\
\text { rzalne, a końcowa ocena ma charakter punktowy. }\end{array}$ \\
\hline $\begin{array}{l}\text { Czy zastosowane kryteria pozwalają ocenić ban- } \\
\text { ki w sposób kompleksowy i sklasyfikować banki } \\
\text { wg poziomu ryzyka? }\end{array}$ & $\begin{array}{l}\text { Tak, oceniana jest efektywność, wypłacalność, } \\
\text { płynność, jakość aktywów, przy czym kryteria } \\
\text { związane z bezpieczeństwem mają największą } \\
\text { wagę w ogólnej ocenie. }\end{array}$ \\
\hline $\begin{array}{l}\text { Czy jednostki zarządzające IPS-ami wydają } \\
\text { zalecenia bankom spółdzielczym? }\end{array}$ & $\begin{array}{l}\text { Tak, wydawane są zalecenia, których celem ma } \\
\text { być poprawa sytuacji finansowej banku. }\end{array}$ \\
\hline $\begin{array}{l}\text { Czy monitoring banków spółdzielczych ma } \\
\text { charakter stały? }\end{array}$ & Tak. \\
\hline $\begin{array}{l}\text { Czy nadawana bankom spółdzielczym ocena ma } \\
\text { walor prognostyczny? }\end{array}$ & Oceny mają ograniczony walor prognostyczny. \\
\hline
\end{tabular}

Źródło: opracowanie własne.

styczna ocen jest bardzo ograniczona. Zwraca na to uwagę Piechocka-Kałużna, pisząc, że ,trzeba doprowadzić do tego, aby system mógł spełniać funkcje prewencyjne, był systemem wczesnego reagowania (...)" [Piechocka-Kałużna 2017, s. 283].

$\mathrm{Z}$ perspektywy bezpieczeństwa banków znaczenie ma nie tylko ocena ich standingu, ale również możliwość wydawania na podstawie oceny zaleceń. Ten warunek jest w polskich IPS-ach spełniony. System wydając zalecenia, może dyscyplinować banki i motywować je do poprawy wyników finansowych.

Istotne znaczenie we wzmacnianiu bezpieczeństwa mają również realizowane przez IPS-y cyklicznie audyty banków spółdzielczych dotyczące ryzyka kredytowego, płynności i adekwatności kapitałowej. Pozwalają one bowiem głębiej przyjrzeć się metodom i procesom zarządzania ryzykiem w tych obszarach, co może stać się impulsem do ich poprawy. Elementem cyklicznych audytów powinna stać się w przyszłości odporność banków na cyberzagrożenia. Stają się one bowiem coraz ważniejszym wyzwaniem dla banków w dziedzinie bezpieczeństwa.

IPS-y wzmacniają bezpieczeństwo banków spółdzielczych, narzucając im zgodne z rozporządzeniem CRR limity w zakresie płynności i wypłacalności. Ważne w tym kontekście są konsekwencje nieprzestrzegania limitów zobowiązujące banki do realizacji planu naprawy.

Przechodząc do oceny mechanizmów wsparcia finansowego banków, warto w pierwszej kolejności przedstawić kryteria ich oceny. Według EBC należy sprawdzić, czy IPS przeprowadza testy warunków skrajnych w celu określenia koniecznej wielkości funduszy, czy utworzono fundusz ex ante, czy środki zgromadzone w funduszach są inwestowane wyłącznie w płynne aktywa [ECB 2016, s. 6-7]. Ważne jest również klarowne zobowiązanie do zapewnienia wsparcia, struktura decyzyjna umożliwiająca terminowe wsparcie oraz zdolność finansowa do zapewnienia wsparcia [Vesala 2016, s. 8]. Z punktu widzenia bezpieczeństwa banków spółdzielczych istotne znaczenie mają także dostępne narzędzia wsparcia oraz moż- 
liwość przeprowadzania wsparcia warunkowego. Warunkowość wsparcia ogranicza hazard moralny, który mógłby skłaniać banki do podejmowania nadmiernego ryzyka.

Mechanizm płynnościowy opiera się na depozytach obowiązkowych. Jego wartość to 9 proc. średniego stanu depozytów, które zostały zgromadzone w bankach-uczestnikach systemów [Sprawozdanie... 2017, s. 10]. Środki IPS-y inwestują w aktywa o wysokiej płynności. Wielkość środków zgromadzonych jest relatywnie wysoka i powinna w przypadku wystąpienia problemów z płynnością gwarantować ochronę, jednak należy pamiętać, że natura problemów z płynnością ma często charakter nagły, nieprzewidywalny, psychologiczny, stąd też trudno określić skalę potrzebnych środków.

Mechanizm pomocowy (zabezpieczający) polega na obowiązkowych wpłatach członków IPS-u. Utworzony fundusz ma zabezpieczać wypłacalność banków i jest tworzony ex ante, co należy pozytywnie ocenić z perspektywy bezpieczeństwa. IPS-y mogą wspierać banki spółdzielcze w momencie zagrożenia niewypłacalnością, wykorzystując następujące narzędzia: udzielanie pożyczek, gwarancji i poręczeń, obejmowanie udziałów w bankach-uczestnikach systemu. Wymienione instrumenty stanowią najczęściej stosowane na świecie narzędzia wsparcia w funduszach pomocowych, co stwarza podstawy do skutecznej pomocy.

Od początku istnienia IPS-ów wzrastała ich zdolność do zapewnienia wsparcia finansowego banków. Według KNF ,uczestnicy IPS dysponują stosunkowo dużymi środkami zgromadzonymi na rachunkach depozytu obowiązkowego w bankach zrzeszających oraz funduszami pomocowymi" [KNF 2018, s. 19]. Wielkość funduszy należy zatem obecnie oceniać pozytywnie z punktu widzenia bezpieczeństwa banków.

Tabela 2. Łączna wielkość depozytu obowiązkowego i funduszu pomocowego w IPS-ach BPS i SGB w 2015 r. i w 2017 r. w mld zł

\begin{tabular}{|l|c|c|c|}
\hline \multicolumn{1}{|c|}{ Element/lata } & 2015 & 2017 & Zmiana \\
\hline Depozyt obowiązkowy & 4,9 & 7,2 & $+2,3$ \\
\hline Fundusz pomocowy & 0,5 & 0,7 & $+0,2$ \\
\hline
\end{tabular}

Źródło: opracowanie własne na podstawie danych KNF.

Od początku istnienia IPS-ów zdeponowane środki i fundusz pomocowy wzrosły odpowiednio o 2,3 mld zł oraz o $0,2 \mathrm{mld}$ zł. Fundusz pomocowy stanowił na koniec 2017 r. 0,67 proc. aktywów banków uczestniczących w IPS-ach (w 2015 r. - 0,64 proc.). Stosunkowo wysoki jest jednak stopień wykorzystania środków pomocowych, który na koniec 2017 r. wyniósł 18,9 proc. IPS-y są pod tym względem zróżnicowane. Poziom wykorzystania środków w IPS SGB wyniósł bowiem 34,7 proc., a w BPS tylko 8 proc.

Pozytywny wpływ na bezpieczeństwo banków spółdzielczych teoretycznie powinna mieć również funkcja standaryzacyjna. Wyznaczanie wspólnych standardów 
w zakresie zarządzania ryzykiem powinno przyczyniać się do poprawy kontroli ryzyka i wzrostu bezpieczeństwa banków.

Zdolność do pokrywania przez system ewentualnych strat jest uwarunkowana nie tylko wielkością dostępnych środków w ramach funduszy wsparcia, ale również kondycją finansową banków spółdzielczych. Warto więc zaprezentować podstawowe wskaźniki charakteryzujące banki spółdzielcze zrzeszone w IPS-ach grupy SGB i BPS, przedstawione w tabeli 3.

Tabela 3. Wskaźniki adekwatności kapitałowej, rentowności i jakości aktywów w polskich IPS-ach w latach 2015-2016 w proc. (zmianę podano w pkt proc.)

\begin{tabular}{|l|c|c|c|}
\hline \multicolumn{1}{|c|}{ Llement } & 2015 & 2016 & Zmiana \\
\hline IPS SGB & 16,09 & 18,02 & $+1,93$ \\
\hline Całkowity współczynnik kapitałowy & 3,8 & 4,15 & $+0,35$ \\
\hline Należności z utratą wartości do ogółu należności & 0,5 & 0,7 & $+0,2$ \\
\hline ROA & 77,4 & 69,5 & $-7,9$ \\
\hline Wskaźnik C/I (koszty operacyjne do dochodów) & b.d. & 17,67 & - \\
\hline IPS BPS & 5,3 & 6,0 & $+0,7$ \\
\hline $\begin{array}{l}\text { Całkowity współczynnik kapitałowy } \\
\text { (dotyczy banków spółdzielczych) }\end{array}$ & 0,5 & 0,54 & $+0,04$ \\
\hline Należności z utratą wartości do ogółu należności & 75,4 & 69,2 & $-6,2$ \\
\hline ROA
\end{tabular}

Źródło: opracowanie własne na podstawie danych zawartych w prezentacji SGB przedstawionej na Forum Liderów Banków Spółdzielczych w 2017 r. oraz w sprawozdaniu dotyczącym Systemu Ochrony Zrzeszenia BPS jako całości za 2016 r. obejmującym: zagregowany bilans, zagregowany rachunek zysków i strat, sprawozdanie na temat sytuacji i sprawozdanie na temat ryzyka, SOZ BPS, Warszawa 2017, s. 4-6.

Banki spółdzielcze z IPS-u grupy SGB w okresie 2015-2016 poprawiły poziom wypłacalności (adekwatności kapitałowej), o czym świadczy wzrost całkowitego współczynnika kapitałowego z 16,09 proc. do 18,02 proc. Warto jednak zaznaczyć, że ,przyrost współczynników kapitałowych w bankach objętych IPS wystąpił między innymi z powodu zmniejszenia wagi ryzyka (...)" [NBP 2017, s. 125]. Wzmocnieniu uległa również rentowność, przy czym trzeba zauważyć, że jest ona relatywnie niska. Banki spółdzielcze mają bowiem problemy z efektywnością kosztową, co wg NBP wynika „z ograniczonych możliwości wykorzystania korzyści skali, niższego niż w innych bankach poziomu informatyzacji, nieproporcjonalnie dużej liczby placówek oraz wysokiego zatrudnienia (...)" [NBP 2017, s. 119]. W przypadku systemu ochrony BPS tendencje w zakresie analizowanych wskaźników są zbieżne z tymi, które odnotowano w IPS-ie SGB. Poziom skonsolidowanego wskaźnika płynności LCR w obu IPS-ach pozwala stwierdzić, że nie ma obecnie w bankach spółdzielczych problemów z płynnością [KNF 2017b]. 
Relatywnie dobry standing banków w ramach IPS-ów potwierdzają oceny wewnętrzne nadane bankom przez jednostki zarządzające. Standing banków oceniany jest w skali punktowej od 1 (najwyższa ocena) do 5 (ocena najsłabsza). 87 proc. banków zrzeszonych w SGB uzyskało w I półroczu 2017 r. ocenę co najmniej na poziomie 1,5 (w tym 30 proc. ocenę najwyższą - na poziomie 1) [System IPS... 2017]. W przypadku systemu BPS średni poziom ocen wyniósł 2 i od początku istnienia systemu uległ poprawie [System Ochrony... 2017].

Z przedstawionej analizy wynika, że banki spółdzielcze w IPS-ach charakteryzują się wysokim poziomem adekwatności kapitałowej i płynności oraz nie generują obecnie nadmiernego ryzyka.

Rola IPS-ów we wzmacnianiu bezpieczeństwa przejawia się również w tym, że poprzez wymianę informacji ograniczana jest asymetria informacyjna w systemie, co powinno zwiększać poziom zaufania banków do banków. Również klienci wiedząc, że o bezpieczeństwo ich banku dba IPS, mogą być bardziej lojalni i mniej podatni na panikę bankową.

Reasumując, przyjęty model IPS-ów powinien odegrać w przyszłości pozytywną rolę we wzmacnianiu bezpieczeństwa i odporności polskich banków spółdzielczych na sytuacje kryzysowe. W ramach badania zidentyfikowaliśmy dwa obszary, które wymagają jednak doskonalenia. Pierwszy obszar związany jest z funkcją monitorującą. Systemy ocen powinny mieć silny walor prognostyczny. Drugim obszarem, który wymaga wzmocnienia, jest fundusz pomocowy. Pomimo relatywnie dobrej sytuacji finansowej banków spółdzielczych stopień wykorzystania środków pomocowych wzrósł. Sugeruje to, że system prawdopodobnie mógłby mieć ograniczoną zdolność do pomocy bankom spółdzielczym w sytuacji większego kryzysu.

\section{Zakończenie}

IPS-y stanowią ważny krok w kierunku wzmocnienia i uzupełnienia architektury bezpieczeństwa banków spółdzielczych poprzez stworzenie mechanizmów monitorująco-pomocowych, które w długoterminowej perspektywie powinny zapewnić bankom spółdzielczym płynność i wypłacalność, minimalizować koszty ewentualnych kryzysów oraz ograniczyć rolę banku centralnego w zapewnianiu awaryjnej płynności bankom spółdzielczym.

Teoretycznie systemy ochrony instytucjonalnej powinny wzmocnić bezpieczeństwo polskich banków spółdzielczych. Decydujące znaczenie mają w tym zakresie jakość mechanizmu wykrywania banków zagrożonych bankructwem oraz przyjęte rozwiązania w zakresie funduszy pomocowych. Dokonana ocena wskazuje, że systemy są poprawnie skonstruowane i dysponują narzędziami umożliwiającymi utrzymywanie wysokiego poziomu bezpieczeństwa.

Postulujemy jednak utworzenie jednego instytucjonalnego systemu ochrony. Istnienie dwóch banków zrzeszających i funkcjonujących wraz z nimi dwóch IPS-ów jest ekonomicznie trudne do uzasadnienia. Za integracją IPS-ów przema- 
wiają korzyści ekonomiczne: efekty skali przy realizacji projektów obejmujących cały sektor, oszczędności na kosztach funkcjonowania spółdzielni zarządzających systemami i korzyści wizerunkowe wynikające z istnienia wspólnej reprezentacji wszystkich banków spółdzielczych. W przyszłości integrację może ułatwić stopniowe zacieranie się różnic między IPS-ami na skutek tego, że są one sterowane przez wspólnego regulatora, czyli KNF.

\section{Literatura}

Benyskiewicz J., Błaszak R., Kosturek Cz., Miętki Z., Narloch A., Pietrzykowski W., Gostomski E. (red.), 2017, Rada nadzorcza w banku spółdzielczym, BODiE, Poznań.

Choulet C., 2017, Institutional protection systems: are they banking groups?, economic-research.bnpparibas.com, http://ecodico.bnpparibas.com/Views/DisplayPublication.aspx?type=document\&IdPdf $=29434$ (dostęp: 26.08.2018).

EACB, 2011, Consultative Document Effective Resolution of Systemically Important Financial Institutions. Recommendations and Timelines, http://www.fsb.org/wp-content/uploads/c_110909v.pdf (dostęp: 26.08.2018).

ECB, 2016, Guide on the approach for the recognition of institutional protection schemes (IPS) for prudential purposes.

Kata R., 2016, Zmiany w mikroekonomicznym i sektorowym modelu bankowości spółdzielczej w Polsce, Stowarzyszenie Ekonomistów Rolnictwa i Agrobiznesu, Roczniki Naukowe, t. XVIII, z. 4.

KNF, 2017a, Informacja o sytuacji banków spótdzielczych i zrzeszajacych w I pótroczu 2017 r., Warszawa, https://www.knf.gov.pl/knf/pl/komponenty/img/Informacja_BS_I_pol_2017_59845.pdf (dostęp: 9.01.2018).

KNF, 2017b, Informacja o sytuacji banków spółdzielczych i zrzeszających w III kwartale 2017 r., Warszawa, https://www.knf.gov.pl/knf/pl/komponenty/img/Raport_Banki_Spoldzielcze_2017_09_ 60666.pdf (dostęp: 9.04.2018).

KNF, 2018, Informacja o sytuacji banków spółdzielczych i zrzeszajacych $w 2017 \mathrm{r}$., Warszawa, https:// www.knf.gov.pl/knf/pl/komponenty/img/Informacja_o_sytuacji_BS_2017_61882.pdf (dostęp: 22.08.2018).

Koleśnik J., 2013, Institutional Protection Scheme w sektorze banków spółdzielczych w Polsce-modelowe rozwiazania, Annales Universitatis Mariae Curie-Skłodowska Lublin - Polonia, Vol. XLVII, 3 , Sectio $\mathrm{H}$.

NBP, 2017, Rozwój systemu finansowego w Polsce w 2016 r., Warszawa.

Piechocka-Kałużna A., 2017, Zalety $i$ wady wprowadzenia systemu ochrony w sektorze banków spótdzielczych w Polsce, Ruch Prawniczy, Ekonomiczny, Socjologiczny, R. LXXIX, z. 4.

Sprawozdanie z działalności Spółdzielni Systemu Ochrony Zrzeszenia BPS za 2016 r., 2017, Warszawa

Statut Spółdzielni Spółdzielczy System Ochrony SGB, http://ips-sgb.pl/wp-content/uploads/2017/07/ 16_Statut_Spółdzielni.pdf (dostęp: 24.08.2018).

System IPS w zrzeszeniu SGB, 2017, prezentacja z Forum Liderów Banków Spółdzielczych wygłoszona przez A. Skowrońskiego, http://konferencje.alebank.pl/wp-content/uploads/2017/09/System-IPS-w-zrzeszeniu-SGB-IPS-SGB.pdf (dostęp: 9.01.2018).

System Ochrony SGB - innowacyjna ochrona banków spółdzielczych, 2016, https://bs.net.pl/system-ochrony-sgb-innowacyjna-ochrona-bankow-spoldzielczych/(dostęp: 1.02.2018).

System Ochrony Zrzeszenia BPS - stan obecny $i$ wyzwania, prezentacja z Forum Liderów Banków Spółdzielczych wygłoszona przez S. Czopura, http://konferencje.alebank.pl/wp-content/ uploads/2017/09/Systemu-Ochrony-Zrzeszenia-BPS.pdf (dostęp: 9.01.2018). 
Szambelańczyk J., 2017, Rola Banku Zrzeszającego po utworzeniu Zrzeszeniowego Systemu Ochrony Instytucjonalnej, https://bs.net.pl/rola-banku-zrzeszajacego-po-utworzeniu-zrzeszeniowego-systemu-ochrony-instytucjonalnej/(dostęp: 1.02.2018).

Vesala J., 2016, Public consultation on how to assess institutional protection schemes, prezentacja European Central Bank Banking Supervision.

Ustawa z dnia 7 grudnia 2000 r. o funkcjonowaniu banków spółdzielczych, ich zrzeszaniu się i bankach zrzeszających, Dz.U. z 2018 r. poz. 613.

Zygierewicz M., 2014, Dylematy zmian instytucjonalnych w polskim sektorze banków spółdzielczych w świetle nowych europejskich regulacji nadzorczych oraz wyników ekonomicznych sektora, Annales Universitatis Mariae Curie-Skłodowska Lublin - Polonia, Sectio H, Vol. XLVIII, 4. 